NAMA : IMAN AHMADI

NIM : 10200120236

Hukum tata negara pada dasarnya adalah hukum yang mengatur organisasi kekuasaan suatu negara beserta segala aspek yang berkaitan dengan organisasi negara tersebut. Sehubungan dengan itu dalam lingkungan Hukum Ketatanegaraan dikenal berbagai istilah yaitu :

Di Belanda umumnya memakai istilah "staatsrech" yang dibagi menjadi staatsrech in ruimere zin (dalam arti luas) dan staatsrech In engere zin (dalam arti luas). Staatsrech in ruimere zin adalah Hukum Negara. Sedangkan staatsrech in engere zin adalah hukum yang membedakan Hukum Tata Negara dari Hukum Administrasi Negara, Hukum Tata Usaha Negara atau Hukum Tata Pemerintah.Di Inggris pada umumnya memakai istilah "Contitusional Law", penggunaan istilah tersebut didasarkan atas alasan bahwa dalam Hukum Tata Negara unsur konstitusi yang lebih menonjol.

Di Perancis orang mempergunakan istilah "Droit Constitutionnel" yang di lawankan dengan "Droit Administrative", dimana titik tolaknya adalah untuk membedakan antara Hukum Tata Negara dengan Hukum Aministrasi Negara.

Sedangkan di Jerman mempergunakan istilah

Verfassungsrecht: Hukum Tata Negara dan Verwassungsrecht: Hukum Administrasi negara.

Pengertian hukum tata negara menurut para ahli, terdiri atas:

1. Menurut Van Vollenhoven

Hukum Tata Negara adalah Hukum Tata Negara yang mengatur semua masyarakat hukum atasan dan masyarakat Hukum bawahan menurut tingkatannya dan dari masing-masing itu menentukan wilayah lingkungan masyarakatnya. dan akhirnya menentukan badan-badan dan fungsinya masing-masing yang berkuasa dalam lingkungan masyarakat hukum itu serta menentukan sususnan dan wewenang badan-badan tersebut.

\title{
2.Menurut Scholten
}

Hukum Tata Negara adalah hukum yang mengatur organisasi dari pada Negara. Kesimpulannya, bahwa dalam organisasi negara itu telah dicakup bagaimana kedudukan organ organ dalam negara itu, hubungan, hak dan kewajiban, serta tugasnya masing-masing.

3.Menurut Van der Pot 
Hukum Tata Negara adalah peraturan-peraturan yang menentukan badan-badan yang diperlukan serta wewenang masing-masing, hubungannya satu dengan yang lain dan hubungan dengan individu yang lain.

\section{Menurut Apeldoorn}

Hukum Tata Negara dalam arti sempit yang sama artinya dengan istilah hukum tata negara dalam arti sempit, adalah untuk membedakannya dengan hukum negara dalam arti luas, yang meliputi hukum tata negara dan hukum administrasi negara itu sendiri.

\section{Menurut Paton George Whitecross}

Hukum Tata Negara adalah hukum yang mengatur alat-alat perlengkapan negara, tugasnya ,wewenang dan hubungan antara alat pelengkap negara itu. Dalam bukunya "textbook of Jurisprudence" yang merumuskan bahwa Constutional Law deals with the ultimate question of distribution of legal power and the fungctions of the organ of the state.

Ruang lingkup kajian hukum tata negara antara lain meliputi, bentuk negara, bentuk pemerintahan, sistem pemerintahan, corak pemerintahan, sistem pendelegasian kekuasaan negara, garis-garis besar tentang organisasi pelaksana, wilayah negara, hubungan antara rakyat dengan negara, cara-cara rakyat menjalankan hak-hak ketatanegaraan, dasar negara dan ciri-ciri lahir kepribadian negara termasuk lagu kebangsaan, bahasa nasional, lambang bendera dan lain sebagainya.

Sumber sumber hukum tata negara dibagi menjadi 2 yaitu:

\section{Sumber hukum materil}

Sumber hukum materiil adalah tempat atau asal mula darimana hukum itu diambil. Sumber hukum materiil berkaitan erat dengan keyakinan akan perasaan hukum individu dan pendapat umum yang menentukan isi hukum. Keyakinan atau perasaan individu (anggota masyarakat) dan pendapat hukum (legal opinion) dapat menjadi sumber hukum materiil. Selain itu, sumber hukum materiil juga bisa berupa hal-hal yang mempengaruhi pembentukan hukum seperti materiil juga bisa berupa hal-hal yang mempengaruhi pembentukan hukum seperti pandangan hidup, hubungan sosial dan politik, situasi ekonomi, corak, peradaban (agama dan kebudayaan) serta letak geografis dan konfigurasi internasional.

\section{Sumber hukum formil}

Sumber hukum formiil adalah sumber hukum yang dikenal dan digali dalam bentuknya (peraturan perundang-undangan). Karena bentuknya tersebut maka sumber hukum formiil diketahui dan diataati sehingga memperoleh kekuatan hukum. Perlu diketahui bahwa selama belum mempunyai bentuk, maka suatu hukum baru hanya merupakan perasaan hukum atau cita-cita hukum yang belum mempunyai kekuatan mengikat. Sumber hukum terdiri dari UU (statute), kebiasaan (custom), keputusan-keputusan hakim (jurisprudence), traktat, dan pendapat serjana hukum (doktrin). Selain lima sumber hukum tersebut, juga 
terdapat sumber hukum yang tidak formal yaitu revolusi (coup d'etat).

Asas asas hukum tata negara :

1. Asas Pancasila

Asas Pancasila merupakan prinsip dasar dan utama dalam kehidupan negara Indonesia.

Pancasila dijadikan pedoman hidup dan memiliki 5 butir nilai, yang mana aturan manapun termasuk undang-undang harus mengikutinya.

5 butir nilai Pancasila diantaranya:

Ketuhanan Yang Maha Esa, Kemanusiaan yang adil dan beradab, Persatuan Indonesia, Kerakyatan yang dipimpin oleh khidmat dalam kebijaksanaan permusyawaratan, Keadilan sosial bagi seluruh rakyat Indonesia.

Apabila suatu undang-undang dibentuk dengan menyalahi asas Pancasila, maka aturan tersebut wajib untuk dicabut, tidak diberlakukan atau direvisi.

2. Asas Negara Hukum

Asas negara hukum menyatakan bahwa negara Indonesia merupakan negara yang berlandaskan hukum. Pernyataan ini juga disampaikan di Undang-undang Dasar 1945.

Negara hukum bermakna bahwa suatu negara tersebut memihak akan keadilan dan kesejahteraan rakyat, bukan atas dasar kekuasaan pemerintah semata.

\section{Asas Negara Kesatuan}

Asas negara kesatuan merupakan prinsip dasar bahwa suatu negara tersebut merupakan negara berdaulat sebagai satu kesatuan.

Negara kesatuan menjadikan suatu pemerintahan pusat adalah puncak dari segala pemerintahan dan kekuasaan yang ada dipilih oleh pemerintah pusat.

\section{Asas Kedaulatan Rakyat}

Kedaulatan memiliki arti lain sebagai kekuasaan pemerintahan. Asas kedaulatan rakyat berarti prinsip negara yang menunjukkan bahwa kekuasaan pemerintah berada di tangan rakyat, untuk rakyat, oleh rakyat. Asas ini tertuang dalam UUD 1945 yang menjelaskan bahwa pemikiran dan ide berasal dari rakyat, atas persetujuan rakyat dan dilakukan oleh Majelis Permusyawaratan Rakyat.

\section{Asas Pembagian Kekuasaan}

Asas pembagian kekuasaan menunjukkan bahwa negara Indonesia memiliki prinsip 
membagi kekuasaan di setiap daerah. Hal ini dilakukan agar tidak terjadinya kekuasaan semena-mena yang dilakukan oleh satu pemimpin atau kelompok. Oleh karenanya dibagilah kekuasaan tersebut untuk mencegah pemimpin atau kelompok mendapatkan kuasa yang terlalu banyak. Meski begitu, masing-masing kekuasaan tetap saling bekerja sama satu sama lain.

\section{Sejarah ketatanegaraan Indonesia}

Secara garis besar sejarah perkembangan ketatanegaraan Indonesia dapat dibagi dalam 4 periode, yaitu:

a. Periode pertama yang berlangsung pada 17 Agustus - 27 Desember 1949,

UUD yang berlaku adalah UUD 1945 ditetapkan oleh PPKI tanggal 18 Agustus 1945.

Menurut UUD 19945 (pasal 1 ayat 2) yang berdaulat adalah rakyat dan dilakukan MPR yang memiliki wewenang antara lain:

- Menetapkan UUD

- Menetapkan GBHN

- Memilih dan mengangkat

- Mengubah UUD

Presiden dalam menyelenggarakan pemerintahan dibantu oleh wakil presiden dan menterimenteri

Menteri-menteri bertanggung jawab pada presiden

Presiden tidak bertanggung jawab pada DPR, sehingga DPR tidak dapat memberhentikan presiden. Demikian sebaliknya presiden tidak dapat membubarkan DPR. Kedudukan DPR dan presiden sama-sama kuat.

b. Periode kedua yang berlangsung pada 27 Desember 1949 - 17 Agustus 1950

Kekalahan Jepang dari sekutu mengharuskannya menyerahkan wilayah jajahannya.

Kesempatan ini dipergunakan Belanda untuk merebut kembali bekas jajahannya di Indonesia

Indonesia sudah bertekad mempertahankan kemerdekaannya dengan segala upaya dengan semboyan "Sekali merdeka tetap merdeka"

Menyadari hal itu, Belanda mencari cara lain yaitu dengan memecahbelah Indonesia dengan membantu negara-negara kecil

Puncak dari perselisihan Indonesia-Belanda diadakan KMB (Konferensi Meja Bundar) 2 November 1949 yang isinya:

- Didirikan negara-negara RIS

- Penyerahan kedaulatan kepada RIS 
- Didirikan UNI antara RIS dan kerajaan Belanda

c. Periode ketiga yang berlangsung dari 17 Agustus 1950 - 5 Juli 1959

Periode federal dari Undang-Undang Dasar Republik Indonesia Serikat (1949) merupakan perobahan sementara, terjadi penggabungan dengan Republik Indonesia, sehingga akhirnya otinggal tiga negara bagian yaitu Republik Indonesia, Negara Indonesia Timur dan Negara Sumatera Timur.

Akhirnya mendirikan kembali Negara Kesatuan Republik Indonesia 19 Mei 1950.

Kemudian dibentuklah suatu Panitia bersama yang menyusun suatu Rancangan UndangUndang Dasar yang kemudian disahkan pada tanggal 12 Agustus 1950 oleh Badan Pekerja Komite Nasional Pusat dan oleh Dewan Perwakilan Rakyat serta Senat Republik Indonesia Serikat pada tanggal 14 Agustus 1950,

Berlaku Undang-Undang Dasar baru itu pada tanggal 17 Agustus 1950.

Jalan yang ditempuh untuk memeperlakuakan undang-undang dasar 1950 dengan menggunakan pasal 190,127 a dan pasal 191 ayat 2 UUD RIS tentang perubahan undangundang dasar maka dengan undang-undang federal no 7 tahun 1950 lembaran negara RIS 1950 no 56 resmilsh UUD RIS 1950 pada tanggal 17 Agustus 1950.

Undang-Undang dasar 1950 bersifat sementara , ini disebabkan karena badan yang menyusun UUD 1950 merasa dirinya kurang representatif sama halnya dengan badan yang menyusun UUD 1949

Dibawah UUD 1950 sebagai realisasi dari pasal 134 telah dilaksanakan pemilihan umum pada bulan Desember 1955 untuk memilih anggota konstituante Pemilihan umum ini dilaksanakan berdasarkan Undang-Undang No.7 tahun 1953. tanggal 10 Nopember 1956 di Bandung diresmikanlah Konstituante.

Sementara Konstituante yang telah bersidang belum dapat menyelesaikan tugasnya maka situasi di tanah air sedemikian rupa sehingga dikhawatirkan akan timbul perpecahan Untuk mengatasi hal tersebut tanggal 22 April 1959 atas nama pemerintah, Presiden memberikan amanatnya di depan sidang pleno Konstituante yang berisi anjuran agar Konstituante menetapkan saja Undang-Undang Dasar 1945 sebagai Undang-Undang Dasar yang tetap bagi Republik Indonesia.

\section{d. Periode ke empat yang berlangsung dari 5 Juli 1959 - sampai sekarang}

Dengan dekrit Presiden 5 Juli 1959 berlakulah kenbali Undang-Undang Dasar 1945. Dasar hukum dari dekrit ini adalah staatsnoodrecht. Dibawah Undang-Undang Dasar 1945 untuk pertama kali dilaksanakan pemilihan umum pada tanggal 3 Juli 1971, sebagai pelaksanaan dari Undang-Undang No. 15 tahun 1969, Undang-Undang mana adalah pelakssanaan dari ketetapan Majlis Permusyawaratan Rakyat Sementara No. XI/MPRS/1966 jo. No.

XLII/MPRS/1968. Hasil dari pemilihan umum tersebut tanggal 28 Oktober 1971 dilantiklah Dewan Perwakilan Rakyat, dan pada tanggal 1 Oktober 1972 Majlis Permusyawaratan Rakyat dilantik pula. Undang-Undang Dasar 1945 masih bersifat sementara. Kesementaraan ini disebabkan karena Majelis Permusyawaratan Rakyat menurut pasal 3 Undang-Undang 
Dasar 1945 menetapkan Undang-Undang Dasar, dan ini belum pernah dilakukan, walaupun Majlis Permusyawaratan Rakyat hasil pemilihan umum telah dilantik dan kemudian bersidangpada tahun 1973.

Organ dan fungsi kekuasaan negara

Organ negara, merupakan kesatuan untuk mengerjakan sesuatu yang berdasarkan UU atau anggaran dasar berwenang mengemukakan dan merealisasikan kehendak badan hukum. Adapun organ negara menurut UUD 1945 yaitu:

> DPR (Dewan Perwakilan Rakyat)

$>$ DPD (Dewan Perwakilan Daerah)

> MPR (Majelis Permusyawaratan Rakyat)

BPK (Badan Pemeriksa Keuangan)

Presiden dan Wakil Presiden

> MA (Mahkamah Agung)

$>$ MK (Mahkamah Konstitusi)

$>\mathrm{KY}$ (Komisi Yudisial)

Adapula lembaga yang diatur kewenangannya dalam UUD 1945 yaitu TNI, Kepolisian Negara RI, pemda, dan Partai Politik. Adapula lembaga tidak disenut namanya tetapi disebut fungsinya daan kewenangannya dinyatakan akan diatur dengan UU, yaitu bank sentral, Komisi Pemilihan Umum (KPU).

kekuasaan negara antara lain:

a. Kekuasaan legislatif, yaitu kekuasaan untuk membuat atau membentuk undang-undang.

b. Kekuasaan eksekutif, yaitu kekuasaan untuk melaksanakan undang-undang, termasuk kekuasaan untuk mengadili setiap pelanggaran terhadap undang- undang.

c. Kekuasaan federatif, yaitu kekuasaan untuk melaksanakan hubungan luar negeri. 